costa slightly more than twice as long as the second; third threefourths as long as the second; second vein ascending rather sharply to the costa; fourth vein curved at the base, but nearly straight beyond, fifth and sixth sinuous; seventh distinct, long. Halteres pale yellow.

One specimen from Kent, Me., August 19, collected by Mr. C. W. Johnson. Type in the collection of the Boston Society of Natural History.

This species is related to projecta Becker which also occurs generally through New England (Boston, Mass.; Brookline, Mass.; Hanover, N. H.), but differs by having the lower pair of proclinate bristles weaker and the palpi less noticeably enlarged in the male as well as by the absence of a fringe of hairs on the posterior femora and the presence of only two scutellar bristles. It is also much like the European $A$. hortensis Wood, but the hypopygium is bristly.

\title{
THE PANURGINE BEES OF THE GENERA HESPERAPIS, ZACESTA AND PANURGOMIA.
}

\author{
By T. D. A. Cockerell, \\ University of Colorado, Boulder, Colorado.
}

The genus Hesperapis Ckll., 1898, was based on H. elegantula Ckll. from New Mexico. At the present time seven species are assigned to it, the range of the genus being from New Mexico to Southern California. The following table separates the known forms:

Thorax above with moss-like ochraceous hair; abdomen dull ferruginous.....................elegantula Ckll. Thorax with ordinary pubescence; abdomen not red ......... 1

1. Area of metathorax dull, or only the apical part shining.....2 Area of metathorax polished and shining . .............

2. Mesothorax strongly and closely punctured, somewhat shining; male about $11.5 \mathrm{~mm}$. long...........eumorpha (Ckll.)

Mesothorax and scutellum shining, polished, finely punctured; male a little over $6 \mathrm{~mm}$. long............ nitidula Ckll.

Mesothorax and scutellum dull, not evidently punctured semirudis Ckll. 
3. Wings perfectly clear..................... larreøe Ckll. Wings brownish. .......................

4. Wings milky at apex; legs of male wholly black .... olivio Ckll. Wings not milky at apex; male tarsi variably reddish

rhodocerata Ckll.

The description of $q$ rhodocerata, as originally given (Panurgus rhodoceratus, Trans. Am. Ent. Soc., XXIV, p. 148), included the o of $H$. olivio, which is separable with difficulty. The males are more distinct and the $\sigma^{7}$ rhodocerata may be regarded as the type. Both species visit the flowers of Pectis in September.

Zacesta Ashmead, 1899, was described as a member of the Osmiinæ, but Titus (Jn. N. Y. Ent. Soc., XII, p. 26) showed that it was a Panurgid. It comes from Los Angeles County, Cal., and is known only in the male. Examining the type of $Z$. rufipes Ashm. in the U. S. National Museum, I found that it closely resembled Hesperapis as typified by $\boldsymbol{H}$. elegantula. The following characters are noteworthy:

(1) The moss-like ochraceous hair on thorax above, as in typical Hesperapis.

(2) The narrow face and essentially parallel orbits, as in $H$. elegantula.

(3) The orange flagellum, as in $\boldsymbol{H}$. elegantula, but the scape shorter and stouter (sexual character?).

(4) Clypeus has a broad yellow apical band, not seen in Hesperapis (but male of $\boldsymbol{H}$. elegantula is unknown).

(5) Compared with $H$. elegantula has larger, shining, area at base of metathorax.

(6) Venation is as in H. elegantula, except that second submarginal cell is longer, and the lower section of basal nervure descends much less abruptly.

(7) The pygidial plate is long and narrow.

(8) Titus has described the palpi of Zacesta; the first three joints of labial palpi are nearly equal whereas in $H$. elegantula the first is nearly as long as 3 plus 4 , the second somewhat shorter than the first.

Hesperapis, as interpreted above consists of at least two very distinct groups, one typified by $\boldsymbol{H}$. elegantula (type of genus), and the other containing the remaining species. Zacesta is per- 
haps closer to $H$. elegantula than it is to the other species assigned to Hesperapis, and its rank as a genus appears doubtful. I think we must call it Hesperapis (Zacesta) rufipes (Ashm.).

Panurgomia Viereck, 1909, was based on $P$. fuchsi Viereck, from Arizona. The unique specimen, a female, was unfortunately in bad condition. Mr. J. C. Crawford recently wrote me (February, 1916) that he considered the genus identical with Hesperapis, and the type species at least extremely close to $H$. eumorpha Ckll. This led me to reëxamine the type, and I found that it possessed the essential characters, so far as could be seen, of the group of Hesperapis which includes the majority of the species. The entirely dull area of metathorax agrees with the minor group of $H$. eumorpha, etc. The stigma is too large for typical Hesperapis. The clypeus is large, strongly convex, polished and shining. Hence it appears that Panurgomia is a valid subgenus (or genus?) for the group of Hesperapis which excludes the typical species.

\title{
A NEW ENGLAND ORTHOPTERAN ADVENTIVE.
}

\author{
By Albert P. Morse,
} Wellesley College, Wellesley, Massachusetts.

\section{Hapithus vagus sp. nov.}

A large and rather stout member of the genus. Rostrum of the vertex as broad as the basal joint of the antennæ. Antennæ, except the basal joint, long and extremely slender, two or three times as long as the body, pale brown, annulate with dusky on alternate joints, every third annulus darker; this pattern is very noticeable near the base and becomes indistinct apically. Maxillary palpi with last joint slender at base, a little securiform, twice as long as the width of the broadened tip.

Pronotum transverse, narrowed anteriorly, the front margin straight or slightly concave, the hind margin a little convex medially; lateral lobes twice as long as deep, smoothly convex below, the anterior and posterior angles rounded. Tegmina nearly or quite covering the abdomen, those of male flat above; of female a little convex, with densely and irregularly reticulate venation, the lateral field crossed by about seven parallel oblique branches of 

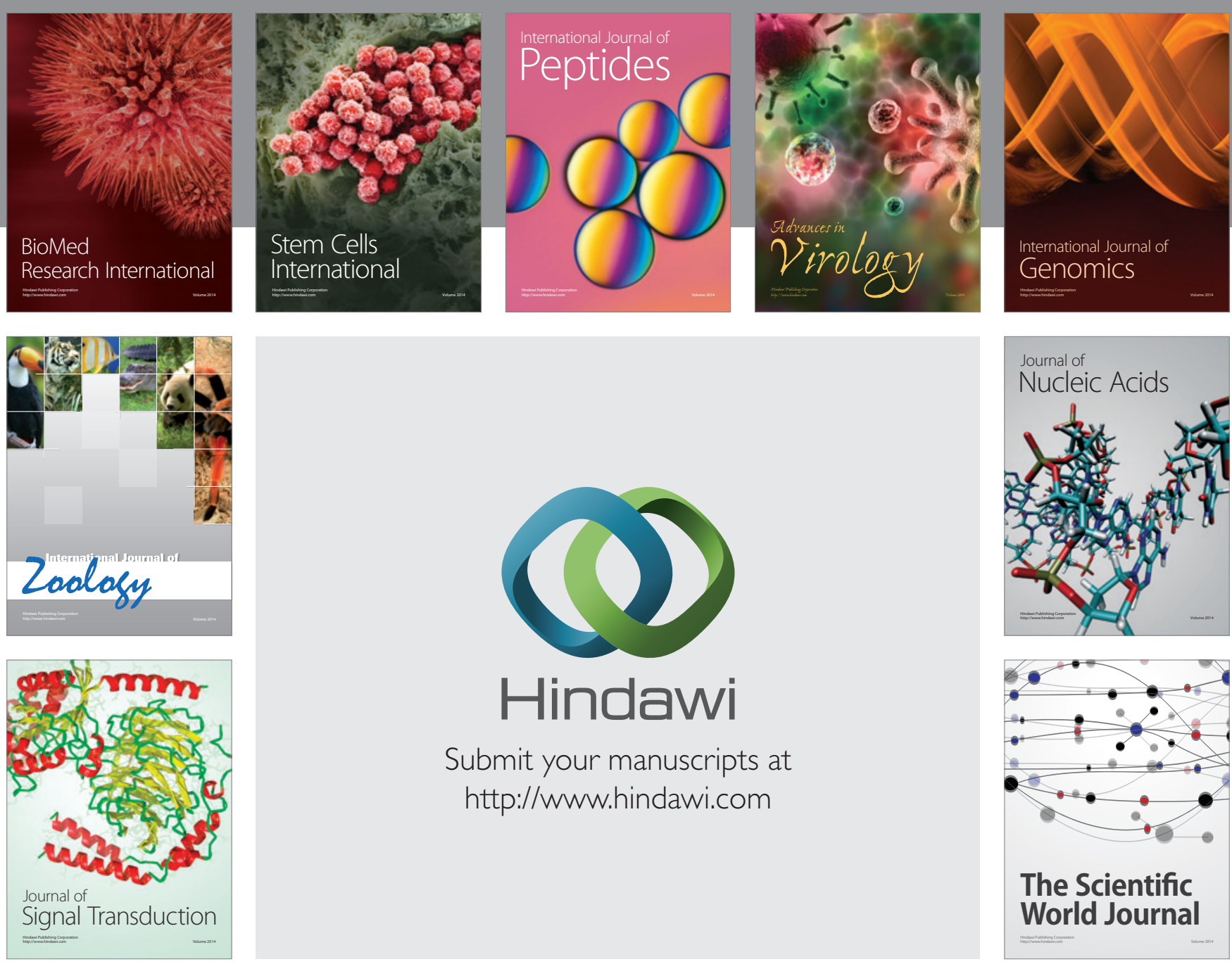

Submit your manuscripts at

http://www.hindawi.com
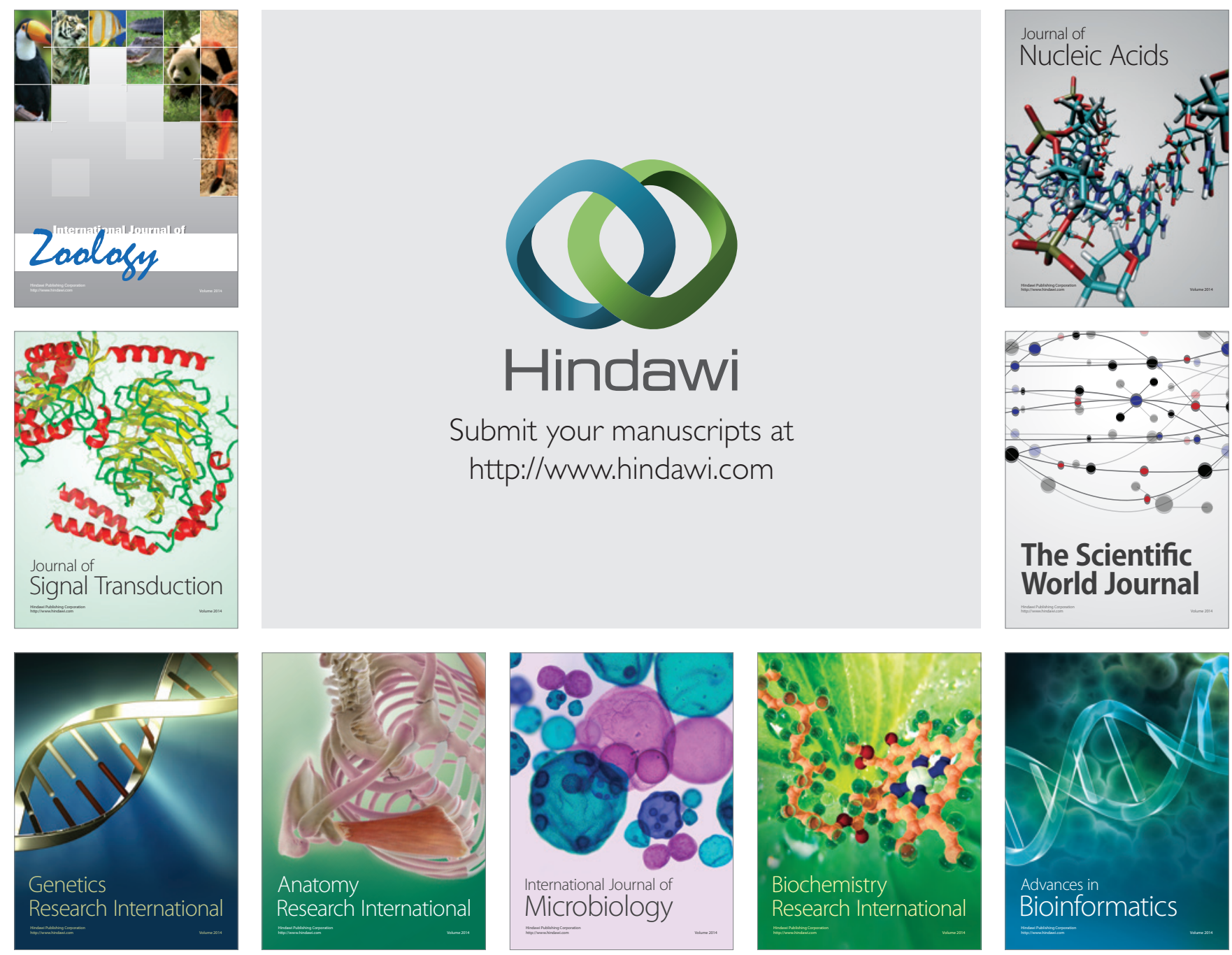

The Scientific World Journal
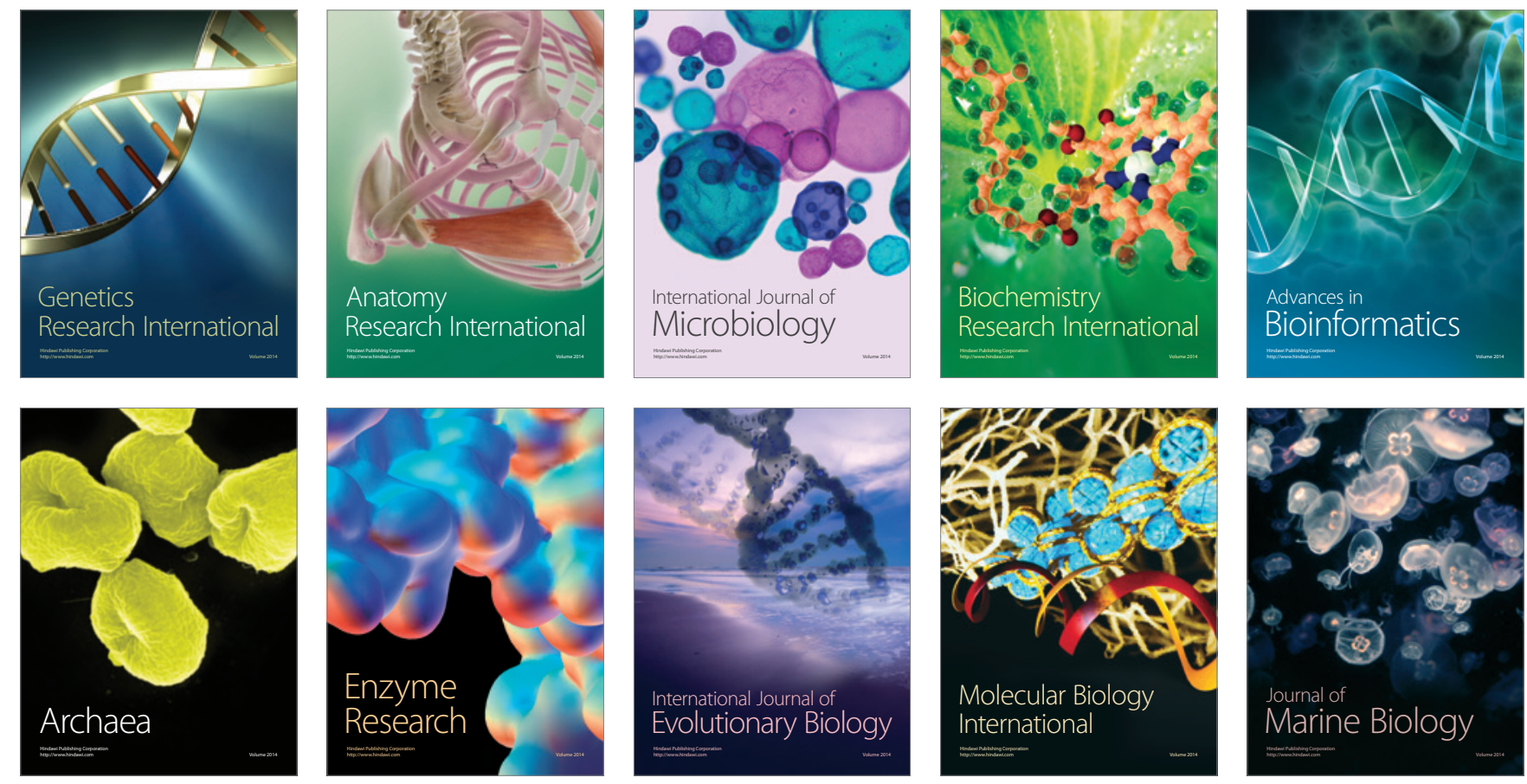